\title{
PLASMA CELL LEUKAEMIA- AN AGGRESSIVE PLASMA CELL DYSCRASIA
}

\author{
Kakchingtabam Urmila1 ${ }^{1}$ Rochitra Khumukcham², Khaidem Tonny Singh ${ }^{3}$, Laiphrakpam Sushila Devi ${ }^{4}$
}

1Postgraduate Trainee, Department of Pathology, Jawaharlal Nehru Institute of Medical Sciences, Imphal. 2Postgraduate Trainee, Department of Pathology, Jawaharlal Nehru Institute of Medical Sciences, Imphal. ${ }^{3}$ Senior Resident, Department of Pathology, Jawaharlal Nehru Institute of Medical Sciences, Imphal.

${ }^{4}$ Associate Professor, Department of Pathology, Jawaharlal Nehru Institute of Medical Sciences, Imphal.

HOW TO CITE THIS ARTICLE: Urmila K, Khumukcham R, Singh KT, et al. Plasma cell leukaemia- an aggressive plasma cell dyscrasia. J. Evolution Med. Dent. Sci. 2017;6(48):3733-3734, DOI: 10.14260/Jemds/2017/806

\section{PRESENTATION OF CASE}

Plasma cell leukaemia is a rare and aggressive variant of plasma cell myeloma having poor outcome. Some improvements in outcome have been made in recent years with newer therapies and stem cell transplantation. Plasma cell leukaemia (PCL) can be primary which arises de novo or evolves as a late feature in the course of plasma cell myeloma (secondary plasma cell leukaemia).

A 40-year-old female presented at the JNIMS Medicine OPD with a history of psychosis, generalised weakness, epistaxis and fever for 5 days. Patient had no history of bone pain. On physical examination, the patient was febrile with marked pallor and splenomegaly. The biochemical profile revealed a decreased serum albumin (3 g/dL), an elevated serum creatinine $(1.8 \mathrm{mg} / \mathrm{dL})$, serum LDH $(521.8 \mathrm{U} / \mathrm{L})$, urea $(62.7$ $\mathrm{mg} / \mathrm{dL}), \beta_{2}$ microglobulin $(5.57 \mathrm{mcg} / \mathrm{mL})$, serum $\mathrm{IgG}_{\mathrm{g}}(3800$ $\mu \mathrm{g} / \mathrm{l})$, serum YGT $(685 \mathrm{U} / \mathrm{L})$, monoclonal spike with $\mathrm{IgG}$, a normal serum calcium ( $9 \mathrm{mg} / \mathrm{dL})$ and alkaline phosphatase (94 U/L). The bone radiography did not show any lytic lesions. Blood for MP and Widal test were also found to be negative.

Initial haematological investigations revealed a low haemoglobin level (8.8 g/dL), leukocytosis $(18,400 /$ cu.mm) with plasmacytoid cells comprising about 25\%, thrombocytopenia (20,000/cu.mm), elevated ESR and an increase in plasma cell count (4600/cu.mm).

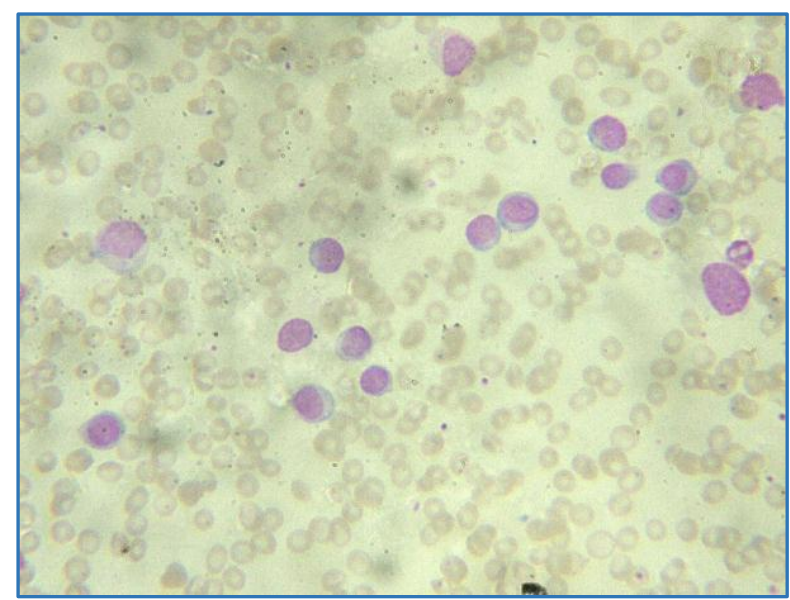

Figure 1. Peripheral Smear shows

Plasmacytosis (Leishman Stain, 10X)

Financial or Other, Competing Interest: None.

Submission 03-05-2017, Peer Review 03-06-2017,

Acceptance 09-06-2017, Published 15-06-2017.

Corresponding Author:

Dr. Kakchingtabam Urmila,

Singjamei Wangma Kshetri Leikai,

Imphal East-795008, Manipur.

E-mail: urmilazk@gmail.com

DOI: $10.14260 /$ jemds $/ 2017 / 806$
Bone marrow aspiration revealed a markedly hypercellular marrow which showed a large number of plasma cells in sheets and dispersion forming about $50 \%$ of marrow cells including plasma blasts.

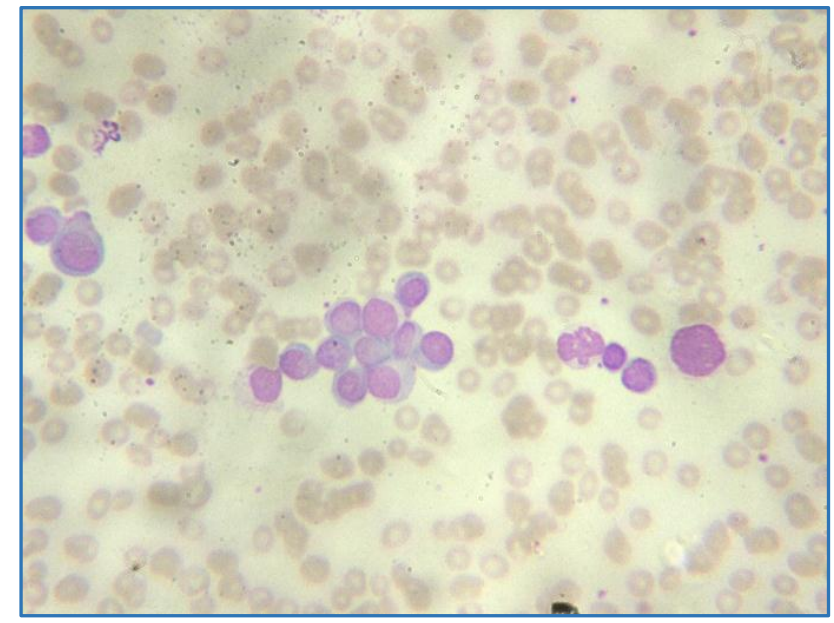

Figure 2. Plasma Cells in Sheets in the Bone Marrow (Leishman stain, 10X)

\section{DIFFERENTIAL DIAGNOSES}

The differential diagnoses of PCL include B-cell chronic lymphocytic leukaemia, hairy cell leukaemia and marginal zone lymphomas with circulating lymphocytes. Reactive polyclonal plasmacytosis related to infections or autoimmune disorders can be differentiated on the basis of absence of kappa or lambda light chain restriction. To differentiate between PCL and other forms of leukaemia, a thorough morphological examination with confirmation by flow cytometry or immunohistochemistry is required.

\section{CLINICAL DIAGNOSIS}

Presenting signs and symptoms include those seen in multiple myeloma (e.g. renal dysfunction, serum biochemical changes) and in other leukaemias (e.g. anaemia, thrombocytopenia, infections and splenomegaly).

Plasma cell leukaemia occurs in all races and all geographic locations. As with multiple myeloma, plasma cell leukaemia is more common in African, American and blacks from Africa than in whites. ${ }^{1}$ Primary plasma cell leukaemia is important to recognise because of its rarity of occurrence with distinct biological, clinical and laboratory features. This rarity of PCL can be assessed from the fact that at MD Anderson Cancer Centre, 27 patients with PCL were seen in 20 years period whereas at Policlinico San Matteo in Italy, 15 cases were seen in 15 years both representing $2-5 \%$ of total cases of multiple myeloma seen at these centres. ${ }^{2,3}$

According to an early survey of published case, primary PCLs account for about $60 \%$ and secondary PCLs for about 
$40 \%$ of cases. ${ }^{4}$ Clinically, the age of presentation of PCL is younger with presence of hepatosplenomegaly and few lytic lesions in the bone compared to the plasma cell myeloma. The median age of PCL is 55 years whereas that for the MM patient is 65 years. ${ }^{5}$ The overall incidence of PCL is less than one case/million population. ${ }^{6}$ There appears to be a $3: 2$ male to female sex distribution in both primary and secondary. ${ }^{5}$

\section{PATHOLOGICAL DISCUSSION}

The diagnosis of PCL is made based upon an evaluation of the peripheral blood smear, bone marrow aspiration, biopsy and protein electrophoresis. The first case of PCL was recognised in the early of the twentieth century. ${ }^{7}$ This uncommon form of plasma cell dyscrasia is the most aggressive variant of all the monoclonal gammopathies and is defined as $>20 \%$ plasma cells in peripheral blood or absolute plasma cell count $>2 \times 10^{9} / \mathrm{L}$ of the differential count. ${ }^{8,9}$ In addition to peripheral blood and bone marrow, the neoplastic plasma cells may be found in the extramedullary tissues, such as spleen and liver, in pleural effusions, ascites and CSF. ${ }^{10}$ Prognosis of plasma cell leukaemia is generally very poor with a median survival of 2 8 months and secondary plasma cell leukaemia have a worse prognosis with a shorter survival than that of primary plasma cell leukaemia. ${ }^{11,12}$

The incidence of plasma cell leukaemia ranges between $2 \%$ and $4 \%$ of patients with plasma cell dyscrasias. ${ }^{13}$

A feared and potentially fatal complications is tumour lysis syndrome. This syndrome has been reported after infiltration of chemotherapy but may occur prior to it. ${ }^{14}$ Increased serum $\beta_{2}$-microglobulin $\left(\beta_{2}-M\right)$ shed from the neoplastic plasma cells reflect tumour burden. As it is excreted by the kidneys high $\beta_{2}$-M are seen in the setting of renal failure as in our case. Hypoalbuminaemia may reflect IL- 6 mediated suppression of hepatocyte albumin production. Hypercalcaemia in plasma cell leukaemia is profound with extensive osteolytic lesion. Increased serum alkaline phosphatase is also associated with increased osteoclastic resorption of bone. In our case, serum calcium and serum alkaline phosphatase were within normal limit which are probably related with the absence of lytic bone lesion. Certain cytogenetic abnormalities may be associated with PCL e.g. $t(4 ; 14), t(14 ; 16)$, del(17p) which are known to confer a poor outcome. Such analysis was not done in our case. Markers of neoplastic cells in primary PCL differ from those of myeloma patients although there may be some overlapping. PCL plasma cells more frequently express $\mathrm{CD}_{20}$ antigen compared to that of multiple myeloma and often lack $\mathrm{CD}_{56}$ antigen which is present on the majority of the myeloma cells. The neoplastic cells in the present case show $\mathrm{CD}_{20}{ }^{+}$and $\mathrm{CD}_{56}{ }^{-}$.

In our case, as soon as the patient was diagnosed with plasma cell leukaemia, the patient was referred to a higher centre on request but unfortunately patient expired 3 days later.

\section{DISCUSSION OF MANAGEMENT}

Treatment is aimed at prolonging the lifespan of PCL patients. Therefore, patients are treated with aggressive induction therapy followed by HCT (Haematopoietic stem cell transplantation) along with good supportive care. Various new drugs with good survival rate have been reported e.g. Thalidomide, Revlimid, Bortezomib, etc. Many more drugs are under investigation that may prolong survival rate with minimal side effects. Despite these progresses, the prognosis of primary PCL still remains unsatisfactory. Our patient expired before initiation of treatment.

\section{FINAL DIAGNOSIS}

After clinicopathological correlation, the patient was diagnosed as having Primary Plasma Cell Leukaemia.

\section{REFERENCES}

[1] Ramsingh G, Mehan P, Luo J, et al. Primary plasma cell leukemia: a surveillance, Epidemiology and End Results database analysis between 1973 \& 2004. Cancer 2009;115(24):5734-9.

[2] Dimopoulos MA, Palumbo A, Delasalle KB, et al. Primary plasma cell leukaemia. Br J Haematol 1994;88(4):7549.

[3] Bernasconi C, Castelli G, Pagnucco G, et al. Plasma cell leukemia: a report on 15 patients. Eur J Hematol Suppl 1989;51:76-83.

[4] Jameel A. Plasma cell leukemia: case report of a rare and aggressive variant of multiple myeloma. Journal of Pakistan Medical Association 2005;55(10):452-3.

[5] Tiedemann RE, Gonzalez-Paz N, Kyle RA, et al. Genetic aberrations and survival in plasma cell leukaemia. Leukemia 2008;22(5):1044-52.

[6] Kosmo MA, Gale RP. Plasma cell leukemia. Semin Hematol 1987;24(3):202-8.

[7] Gluzinski A, Reichenstein M. Myeloma and leucaemia lymphatica plasma cellularis. Wein Klin Wochenschr 1906;19:336.

[8] Kyle RA, Maldonado JE, Bayrd ED. Plasma cell leukemia. Report on 17 cases. Arch Intern Med 1974;133(5):8138.

[9] Noel P, Kyel RA. Plasma cell leukemia: an evaluation of response to therapy. Am J Med 1987;83(6):1062-8.

[10] McKenna RW, Kyle RA, Kuehl WH, et al. Plasma cell neoplasms. In: WHO Classification of tumors of hematopoietic and lymphoid tissues. IARC Lyon 2008:200-13.

[11] Costello R, Sainty D, Bouabdallah R, et al. Primary plasma cell leukemia: a report of 18 cases. Leuk Res 2001;25(2):103-7.

[12] Wohrer S, Ackermann J, Baldia C, et al. Effective treatment of primary cell leukemia with the thalidomide and dexamethasone - a case report. Hematol J 2004;5(4):361-3.

[13] Garcia-Sanz R, Orfaco A, Gonzalez M, et al. Primary plasma cell leukemia: clinical, immunophenotypic, DNA ploidy and cytogenetic characteristics. Blood 1999;93(3):1032-7.

[14] Jaskiewicz AD, Herrington JD, Wong L. Tumor lysis syndrome after bortezomib therapy for plasma cell leukemia. Pharmacotherapy 2005;25(12):1820-5. 